\title{
Completion of field work for the 1:500 000 mapping and regional geological studies in central and western North Greenland
}

\author{
Niels Henriksen
}

Field activities comprising the second, and final season of the systematic field mapping programme in central and western North Greenland were carried out from June to August 1985. The field investigations were concluded for the 1:500 000 map sheet of the area between J. P. Koch Fjord (c. $\left.40^{\circ} \mathrm{W}\right)$, in the east, and north-easternmost Washington Land $\left(65^{\circ} \mathrm{W}\right)$ in the west; the southern boundary of the map sheet is $81^{\circ} \mathrm{N}$ (fig. 1). General geological investigations formed an integral part of the mapping programme. A special source rock project, financed by the Danish Ministry of Energy, was fully integrated with the mapping programme (Christiansen et al., this report).

As in 1984 a tent base camp in south-eastern Warming Land served as an operation centre for the expedition. Two chartered Jet Ranger helicopters and a Twin Otter aircraft were based here, and served the expedition groups with transport facilities throughout the season. Mobilisation and demobilisation of the expedition from Denmark were carried out with help from the Royal Danish Air Force, who airlifted the expedition to and from the Canadian Forces Station (CFS) Alert in north-east Ellesmere Island, Canada. Personnel, equipment and fuel were flown into the base camp from Alert with the Twin Otter.

The expedition group numbered 40, comprising 12 two-man geological parties, a fourman drilling team and 12 supporting personnel, including aircraft crew members. As in 1984, the operation area extended about $500 \mathrm{~km}$ from east to west, and $150-200 \mathrm{~km}$ from south to north. The 12 geological teams and the drilling team utilised about 130 camp sites.

At the end of the 1985 season, the temporary huts and tents at base camp were dismantled and, together with all the equipment, were taken back to Denmark. Fuel depots and equipment in other parts of the working area, which is part of the North and East Greenland National Park, were also removed.

\section{Geological investigations}

The 1985 programme represented a direct continuation of the activities of the previous year. Many parties completed studies started in 1984, although several new activities were also undertaken. Each of the two-man geological parties worked with specific topics or areas of responsibility. Activities were spread over the whole region but some teams were mainly concentrated in the western areas, while others primarily worked in the east. Compilation of results is now well under way, following completion of field aspects of the mapping and general geological investigations.

Preliminary results from the 1984 field work have been presented in a special report ('Report on the 1984 geological expedition to central and western North Greenland': Rapp. Grønlands geol. Unders. 126, 1985) which also provides a general geological background to the following discussion. The present article is based on an internal GGU report (Express Report, North Greenland 1985), to which all the participating geologists contributed immediately after the end of the field season. 


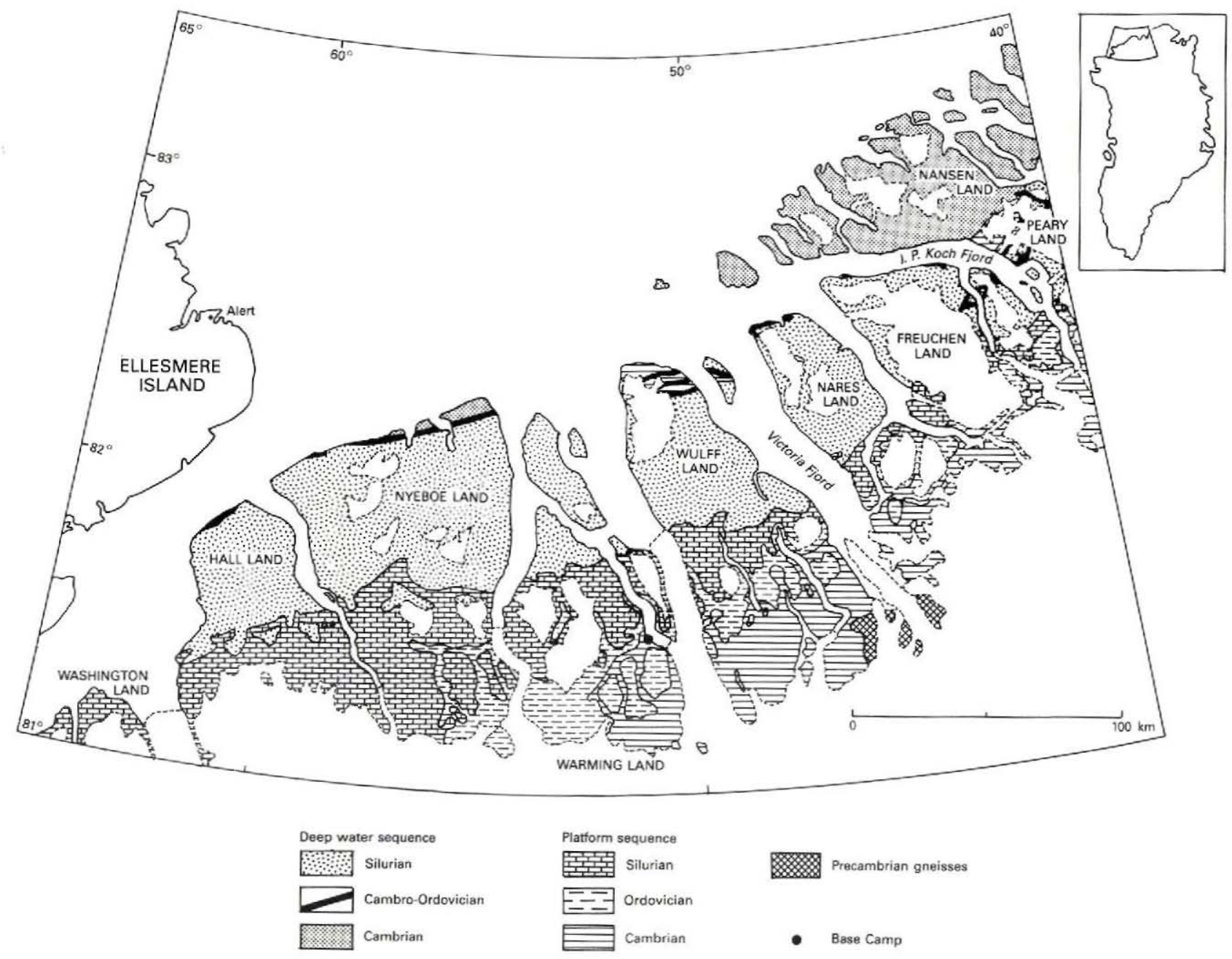

Fig. 1. Geological sketch map of central and western North Greenland. 
The participating geologists and their main work topics and mapping responsibilities were:

(1) J. S. Peel \& M. Blaker:

(2) T. L. Harland \& P.-H. Due:

(3) M. Sønderholm \& L. Nydahl Jørgensen:

(4) F. Surlyk \& J. R. Ineson:
Silurian carbonates in the shelf sequence: lithostratigraphy, palaeontology and sedimentology. Cambrian stratigraphy. Freuchen Land - Nares Land.

Silurian carbonates in the shelf sequence: lithostratigraphy and sedimentology. Wulff Land - Washington Land.

Silurian carbonates in the shelf sequence: lithostratigraphy and sedimentology. Wulff Land - Washington Land.

Cambro-Ordovician: basin analyses Freuchen Land - Nyeboe Land.

(5) H. F. Jepsen \& J. Bender Jørgensen: Late Proterozoic to Silurian stratigraphy and structural geology of Wulff Land: a detailed cross-section from the unfolded shelf sequence to the folded trough.

(6) J. C. Escher \& P.-H. Larsen:

Silurian turbidite sequence: stratigraphy, sedimentology and structural geology. Freuchen.Land - Hall Land.

(7) A. K. Higgins \& N. C. Davis:

Cambro-Ordovician slope and trough: stratigraphy and structural geology. Nansen Land - Nyeboe Land.

(8) J. D. Friderichsen \& H.-J. Bengaard: Deformed Cambrian trough sequence in Nansen Land: lithostratigraphy and structural geology.

(9) H. Stendal \& U. H. Jakobsen:

Reconnaissance geochemical exploration and detailed investigations of previously detected anomalies. Freuchen Land - Hall Land.

(10) N. Abrahamsen \& R. Van der Voo:

Palaeomagnetic and rock-magnetic investigations. Nansen Land - Nyeboe Land.

(11) F. Getreuer Christiansen, O. Nykjær \& H. Nøhr-Hansen

Source rock investigations and shallow core drilling in the Cambro-Silurian sequence. Freuchen Land - Hall Land.

(12) N. Henriksen:

Precambrian crystalline basement of southern Wulff Land.

Lower Palaeozoic strata in North Greenland forms part of a continental margin zone with east-west trending belts of sediments laid down along the northern border of the Precambrian Greenland shield. A Cambro-Silurian shelf sequence dominated by carbonates forms a 3-4 km thick succession with shallow water epicontinental deposits. A slope and deep-water trough sequence of mainly turbiditic sediments with a cumulative thickness of 8-10 km was deposited in Cambro-Silurian time to the north of the shelf. The shelf sequence is generally unfolded and disturbed only by faults. Northwards the deep-water sequence is increasingly affected by Upper Palaeozoic (Ellesmerian) deformation which gave rise to the North Greenland fold belt. 
A few days' reconnaissance work in the exposed areas of the Greenland shield by N. Henriksen supplemented the 1984 work by Henriksen \& Jepsen (1985), and a series of silt and sand samples were taken for Nd-Sm age determinations. The region is dominated by amphibolite banded migmatitic orthogneisses with occasional bands of supracrustal rocks.

The main objective of the 1985 work in the shelf sequence was the mapping and study of the Silurian carbonate succession. In addition, supplementary investigations were carried out in Cambro-Ordovician sequences. The work was undertaken by three teams. Two teams, M. Sønderholm \& L. Nydahl Jørgensen (both GGU) and T. L. Harland (Poroperm, England) and P.-H. Due (GGU), mapped and studied the sequence between Wulff Land and north-easternmost Washington Land. They distinguished three mapping units which could be traced across their whole mapping area. A lower unit of Ordovician-Silurian age includes uniformly developed limestones which form the basal part of the Silurian carbonate sequence and corresponds to the Aleqatsiaq Fjord Formation of Washington Land (Hurst, 1980; fig. 2). Unit 2 is lithologically very diverse and complex and forms the upper part of the Silurian carbonate sequence. It correlates with the Washington Land Group of Hurst (1980) and five sub-units have been recognised. Flat-bedded limestones at the base are overlain by series of mounds and variable intermound sediments. The development reflects differential subsidence of the shelf with a much stronger subsidence in the north, where a complex of major build-ups and ramp deposits were formed. Unit 3 is equivalent to the Lafayette Bugt Formation (fig. 2). It is part of the deep-water sequence which generally is developed to the north of the carbonate shelf, and comprises black mudstones and siltstones with intraformational conglomerates and occasional olistostromes near the shelf edge.

J. S. Peel (GGU) and M. Blaker (Keele University) mapped the eastern part of the Silurian carbonate sequence from J. P. Koch Fjord to southern Nares Land. They found in general the same stratigraphical succession as in the western region, but with a less pronounced development of mounds and biostromes. The Lafayette Bugt Formation is found in southern Nares Land but disappears towards the east. In addition to the work in the Silurian, J. S. Peel and M. Blaker studied aspects of the Cambrian stratigraphy and biostratigraphy initiated by Peel \& Wright (1985) and, among other things, made palaeontological collections from Lower and Middle Cambrian shelf and slope sequences. At the end of the season J. R. Ineson (British Antarctic Survey - BAS) and J. S. Peel investigated the transition in southwest Freuchen Land between the Cambrian Ryder Gletscher Group, in the west, and the Brønlund Fjord and Tavsens Iskappe Groups in the east (fig. 2). This transition reflects two depositional regimes, deposits of mainly platform carbonates in the west passsing eastwards into a prograding succession representing the platform margin and outer shelf-slope.

Finn Surlyk (GGU) and J. R. Ineson (BAS) carried out a general básin analysis mainly of the Cambro-Ordovician shelf and deep-water successions, with some additional investigations in the Silurian turbiditic sequence. Detailed tracing in $\mathrm{N}-\mathrm{S}$ sections of the transition from the carbonate platform to the outer shelf, and across the slope to the deep-water basin, has made possible a fully integrated basin stratigraphy and basin sedimentological synthesis.

A special survey aimed at compiling maps at a scale of 1:100 000 accompanied by constructed profiles from Wulff Land, was continued by H. F. Jepsen and J. Bender Jørgensen (both GGU). Field work in 1985 concentrated on a major WSW-ENE trending strike-slip fault in southern Wulff Land which has a downthrow of up to $600 \mathrm{~m}$, and on structural studies in northern Wulff Land. The aim of these studies is, together with data from other geologists, to compile a N-S cross-section showing the structural development from the platform 


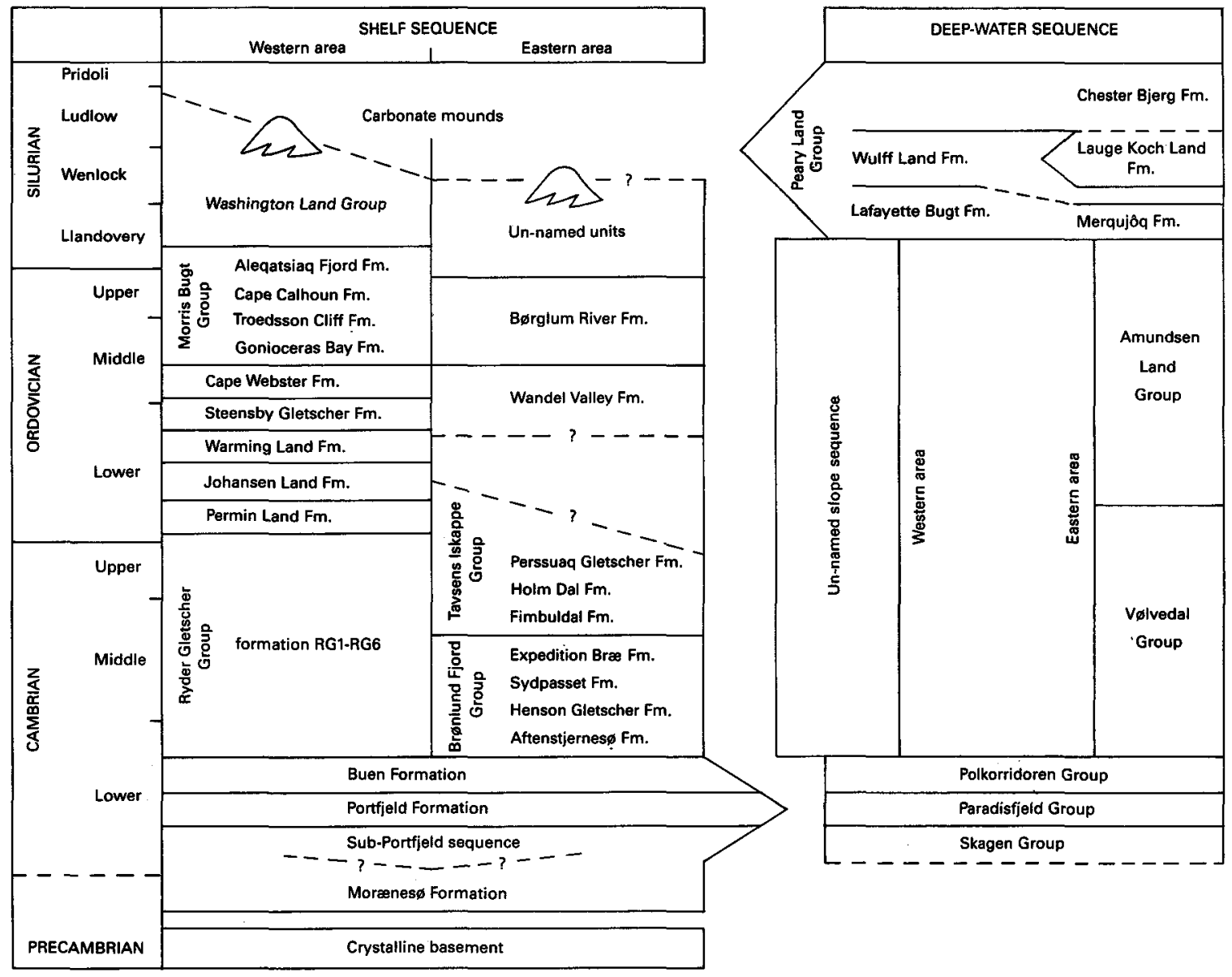

Fig. 2. Schematic summary of stratigraphic nomenclature used in central and western North Greenland. 
in the south to the intensely folded strata on the north. The work is based on field investigations combined with detailed photogrammetric mapping using a computer-aided Kern PG-2 stereoplotter instrument with a semi-automatic drawing table.

Silurian turbidites of the Peary Land Group (fig. 2) - from J. P. Koch Fjord to Nares Land, and in Hall Land - were mappped by J. C. Escher and P.-H. Larsen (both GGU), who continued their 1984 investigations. An almost complete sequence of the Peary Land Group is exposed in Nyeboe Land (Larsen \& Escher, 1985). Several of the lithological units can be traced for $250 \mathrm{~km}$ or more along the main E-W axis of the deep-water basin. Lower parts of the sequence (Merqujôq Formation, Thors Fjord Member and a lower unit of the Lauge Koch Land Formation) are dominant in the east, whereas the upper formations (an upper unit of the Lauge Koch Land Formation and the Chester Bjerg Formation) are also exposed in the west. Structural observations were made along well exposed fjord sections, and many graptolite assemblages were collected from various units.

Stratigraphical and structural investigations in the North Greenland fold belt were continued by two teams. A. K. Higgins (GGU) and N. C. Davis (Sheffield University) mapped Sverdrup $\emptyset$ and other islands west of Nansen Land and continued studies of the zone of thinskinned folding and thrusting between J. P. Koch Fjord and northern Nyeboe Land. H.-J. Bengaard and J. D. Friderichsen (both GGU) worked in the highly folded Cambrian trough sequence in Nansen Land.

Higgins and Davis continued studies on the south to north transition of the siliciclastic Buen Formation (fig. 2), from a thinner shelf development through a three times thicker transitional sequence, into the basinal sequence of the Polkorridoren Group. Structural studies concentrated on the south verging thin-skinned fold and thrust zone along the northern peninsulas between J. P. Koch Fjord and Nyeboe Land and the northerly vergent fold belt in Nansen Land (Soper \& Higgins, 1985). The zone of thrusts was extended westwards, new major low angle thrusts being found in northern Wulff Land and northern Nyeboe Land. In the islands west of Nansen Land, one major phase of folding is distinguished, slightly overturned to the north, and the rocks are slightly metamorphosed.

In Nansen Land, H.-J. Bengaard and J. D. Friderichsen mapped carbonates of the Paradisfjeld Group and turbiditic sandstones and mudstones of the overlying Polkorridoren Group (fig. 2). Five units were distinguished in the latter group in 1984 (Friderichsen \& Bengaard, 1985), and these were mapped westwards in 1985 . The lower unit of mainly siltstones with sandy turbidites includes local large limestone olistoliths and calcareous beds. These are overlain by a unit of turbiditic psammites and two units of banded shales and quartzites. The upper unit of recrystallised mudstone is the equivalent of the Frigg Fjord mudstone of Johannes V. Jensen Land (Higgins et al., 1981). In 1984 three E-W trending sets of folds produced by phases of Ellesmerian deformation and two sets of minor generally N-S trending post-Ellesmerian folds were recognised. Nearly all of these were found again in the area mapped this year, with the first Ellesmerian phase of deformation forming the dominant vertical to north-verging major folds.

A regional geochemical exploration programme comprising sampling of drainage sediments and a detailed follow-up of geochemical anomalies recorded last year, was undertaken by U. H. Jakobsen and H. Stendal (both Copenhagen University). During investigations in the eastern part of the region in 1984 about 500 stream sediment samples were taken, corresponding to one sample per $30 \mathrm{~km}^{2}$ (Steenfelt, 1985). Field work in 1985 included sampling in Nyeboe Land and Hall Land; in all c. 400 samples were collected corre- 
sponding to a density of one sample per $25 \mathrm{~km}^{2}$. As in 1984 the fine-grained stream sediment samples will be analysed and the heavy mineral concentrates studied under the microscope, in order to outline major geochemical provinces and possible mineralised districts. The two seasons' stream-sampling programme has thus covered the whole region between Nansen Land in the north-east and Hall Land in the south-west.

The geochemical follow-up survey was carried out in three different geological environments: (1) at the carbonate shelf edge with enhanced Ba-contents in southern Nares Land; (2) in the Cambro-Ordovician slope sequence (fig. 2) with anomalies of $\mathrm{Ba}$ and $\mathrm{Zn}$ between J. P. Koch Fjord and Nyeboe Land; and (3) in the Silurian turbidite sequence on Castle $\varnothing$ (an island west of Wulff Land) where $\mathrm{Ba}$ and $\mathrm{Zn}$ anomalies have been recorded. The detailed surveys were carried out in these areas collecting both rock and stream sediment samples to obtain a more precise evaluation of the geological relation of the geochemical distribution patterns from the drainage samples. Apart from a local Ba-Zn mineralisation found in 1984 in Freuchen Land (Jakobsen \& Steenfelt, 1985), no mineralisation of major significance has been found in the working area.

The field work for a study of rock magnetism and palaeomagnetism was carried out by $\mathrm{N}$. Abrahamsen (Aarhus University) and R. Van der Voo (Michigan University), who in the field measured susceptibility values ( $K$-values) of induced magnetisation for a variety of rock types and collected orientated rock samples for palaeomagnetic investigations. Similar work was carried out in the Peary Land region to the east in 1979 and 1980 (Abrahamsen \& Marcussen, 1980). The susceptibility and the NRM (natural remanent magnetisation) measurements will be used in connection with the interpretation of previously collected aeromagnetic data, which are at present being reinterpreted in GGU. A total of about 1900 orientated samples from 370 sites were collected for palaeomagnetic investigations. The sampling covered the Precambrian crystalline basement with younger, presumed Proterozoic, basic dykes; a rather complete collection from the uppermost Precambrian (Morænes $\varnothing$ Formation) to Silurian sediments of the shelf; various parts of the Cambro-Silurian deep-water sequence; a series of samples from metamorphic rocks in the fold belt; and a large collection of Tertiary dykes of three different generations.

The source rock project - project 'Nordolie' - continued the systematic sampling of possible petroleum source rocks which began in 1984 (Christiansen et al., 1985). Three geologists (F. Getreuer Christiansen, O. Nykjær and H. Nøhr-Hansen, all GGU), two technicians (J. Boserup and A. Clausen, both GGU) and an assistant (J. Bojesen-Koefoed, Copenhagen University) participated in the project. A programme of shallow core drillings produced unaltered material for organic analyses from the horizons with potential source rocks. Cores were obtained from 13 drill sites, with a maximum drilling depth of about $40 \mathrm{~m}$. Source rocks are mainly found in carbonates and shales of the Cambrian Henson Gletscher Formation in the carbonate shelf sequence, and in black shale and lime mudstones in the Silurian Lafayette Bugt Formation in the slope to deep-water sequence. The Nordolie project is described in more detail by Christiansen et al. (this report).

Oblique aerial photography, in both black and white and colour, was again undertaken along coast and valley sections by $\mathrm{N}$. Henriksen and J. Lautrup (both GGU) using the chartered Twin Otter aircraft. This year's photographic flights supplemented last year's programme (N. Henriksen, 1985) and nearly all major fjord and valley sections in the working area are now covered. In total $c .2100$ black and white photographs in $4.5 \times 6.0 \mathrm{~cm}$ format and $c .750$ colour photographs in $24 \times 36 \mathrm{~mm}$ format were taken in 1985 . 


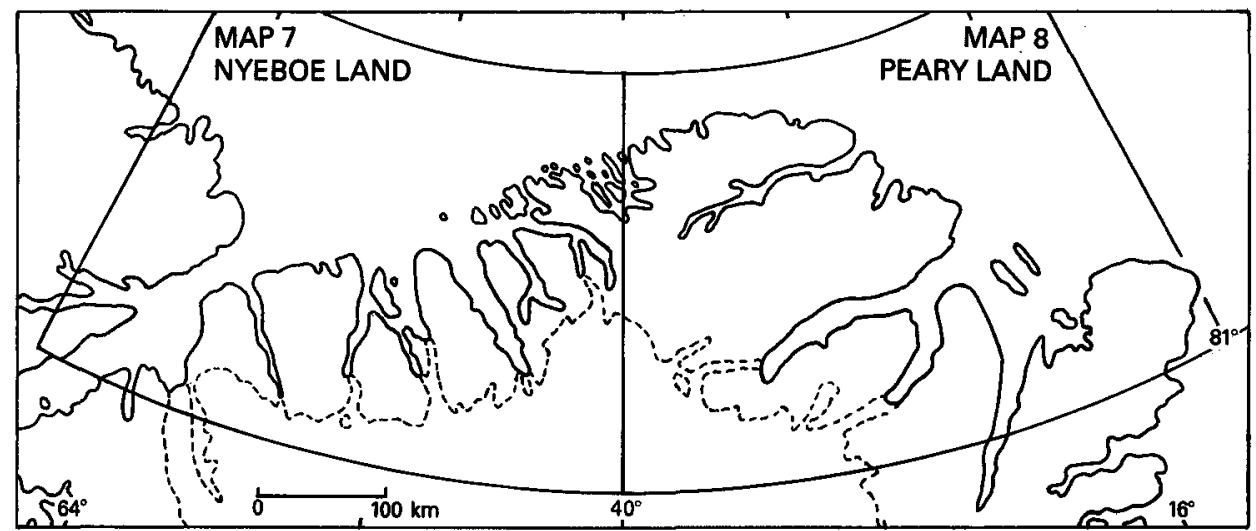

Fig. 3. Regional maps at a scale of 1:500 000 mapped during GGU's North Greenland Project (1978-80, 1984-85).

The completion of field work in 1985 brought to an end the second phase of GGU's North Greenland project (1978-80, 1984-85). The more immediate aspects of the season's work, including a preliminary geological map, will be collected in a special report, as in previous years; the final geological map (fig. 3) will be a fully coloured publication in GGU's 1:500 000 map series. A large quantity of geological information collected through the entire project has already been published, but it is to be expected that evaluation and final publication of data will continue for a number of years.

Acknowledgements. The 1985 field work was carried out with the help of many external institutions and their personnel. The Royal Danish Air Force supplied the C-130 transport aircraft co-ordinated by Major J. F. Clemmensen. The Department of National Defence Headquarters, Ottawa, gave permission to use CFS Alert as supporting base in connection with mobilisation and demobilisation, and this work was co-ordinated by Major E. P. Luhtala and Major R. G. Biggin (both Ottawa). The Commanding Officers at CFS Alert, Major D. Jardine for most of the summer and, later, Major R. H. Addington, and all their personnel were extremely helpful; all arrangements on the station were carried out very efficiently. The Polar Continental Shelf Project, Ottawa, provided hut facilities at Alert, and the Danish Liaison Officer at Thule Air Base, Commander H. Bruun de Neergaard and his staff, helped with co-ordination and communication through Thule Air Base. The Meteorological Institute in Copenhagen gave special weather forecasts for the expedition throughout the season. Colleagues at GGU have provided valuable suggestions and comments on the manuscript.

\section{References}

Abrahamsen, N. \& Marcussen, C. 1980: Preliminary results of rock and palaeomagnetic field work in Peary Land, North Greenland. Rapp. Grønlands geol. Unders. 99, 137-145.

Christiansen, F. G., Nøhr-Hansen, H., Rolle, F. \& Wrang, P. 1985: Preliminary analysis of the hydrocarbon source rock potential of central and western North Greenland. Rapp. Grønlands geol. Unders. 126, 117-128.

Friderichsen, J. D. \& Bengaard, H.-J. 1985: The North Greenland fold belt in eastern Nansen Land. Rapp. Grønlands geol. Unders. 126, 69-78.

Henriksen, N. 1985: Systematic 1:500 000 mapping and regional geological studies in central and western North Greenland. Rapp. Grønlands geol. Unders. 125, 9-17. 
Henriksen, N. \& Jepsen, H. F. 1985: Precambrian crystalline basement at the head of Victoria Fjord, North Greenland. Rapp. Grønlands geol. Unders. 126, 11-16.

Higgins, A. K., Friderichsen, J. D. \& Soper, N. J. 1981: The North Greenland fold belt between central Johannes V. Jensen Land and eastern Nansen Land. Rapp. Grønlands geol. Unders. 106, 35-45.

Hurst, J. M. 1980: Silurian stratigraphy and facies distribution in Washington Land and western Hall Land, North Greenland. Bull. Grønlands geol. Unders. 138, 95 pp.

Jakobsen, U. H. \& Steenfelt, A. 1985: Zinc mineralisation at Navarana Fjord, central North Greenland. Rapp. Grønlands geol. Unders. 126, 105-109.

Larsen, P.-H. \& Escher, J. C. 1985: The Silurian turbidite sequence of the Peary Land Group between Newman Bugt and Victoria Fjord, western North Greenland. Rapp. Grønlands geol. Unders. 126, $47-67$.

Peel, J. S. \& Wright, S. C. 1985: Cambrian platform stratigraphy in the Warming Land - Freuchen Land region, North Greenland. Rapp. Grønlands geol. Unders. 126, 17-24.

Soper, N. J. \& Higgins, A. K. 1985: Thin-skinned structures at the basin-shelf transition in North Greenland. Rapp. Grønlands geol. Unders. 126, 87-94.

Steenfelt, A. 1985: Reconnaissance scale geochemical survey in central and western North Greenland. Preliminary results concerning zinc and barium. Rapp. Grønlands geol. Unders. 126, 95-104.

\title{
Source rock investigations and shallow core drilling in central and western North Greenland - project 'Nordolie'
}

\author{
F. G. Christiansen, O. Nykjær and H. Nøhr-Hansen
}

The aim of project 'Nordolie' (Christiansen \& Rolle, 1985) is to study the distribution and maturity of potential hydrocarbon source rocks in central and western North Greenland.

A first broad reconnaissance and examination of most lithostratigraphic units throughout the region in 1984, followed by organic geochemical and palynofacies analyses, showed that some intervals in the Cambrian shelf sequence and in the Cambrian to Silurian trough sequence are sufficiently rich in organic matter to be considered as potential source rocks (Christiansen et al., 1985). The Cambrian and Ordovician trough sequence is thermally postmature with respect to hydrocarbon generation in the whole area. Consequently the second and final field programme within the project (1985) concentrated on the Cambrian shelf sequence (especially the Henson Gletscher Formation in the Brønlund Fjord Group) and the Silurian slope to trough sequence (Lafayette Bugt Formation and Wulff Land Formation).

The main purpose of the 1985 work was to make a detailed study of these units combining field work and shallow core drilling. The samples and cores provide the basis for later detailed maturity studies and a quantitative evaluation of source rock quality and volume. As in 1984 , the 1985 field season was fully integrated with the geological mapping programme in the region (Henriksen, this report).

The field work was carried out by a team of two geologists and a drilling team with three technicians (John Boserup, Anders Clausen, Jørgen Bojesen-Koefoed) and a drill site geologist. The three geologists alternated often in order to obtain continuity in the programme and furthermore six of the total 14 camps were located at the drill sites (fig. 1). 